\title{
Faktor-Faktor yang Mempengaruhi Kinerja Pemasaran UMKM Aceh di Masa Pandemi Covid 19
}

\author{
MUKHDASIR * \\ Fakultas Ekonomi, Sekolah Tinggi Ilmu Ekonomi Syariah Serambi Mekka, \\ Aceh Jaya, Provinsi Aceh, Indonesia \\ mukhdasir4@gmail.com
}

\begin{abstract}
Article's history:
Received 27 October 2019; Received in revised form 24 February 2020; Accepted 16 February, 2020;

Published 30 February 2020. All rights reserved to the Lembaga Otonom Lembaga Informasi dan Riset Indonesia (KITA INFO dan RISET).
\end{abstract}

\section{Suggested citation:}

Mukhdasir, M., 2020. Faktor-Faktor yang Mempengaruhi Kinerja Pemasaran UMKM Aceh di Masa Pandemi Covid 19. JEMSI (Jurnal Ekonomi, Manajemen, dan Akuntansi), Volume 6 (1): 45-51. DOI: https://doi.org/10.35870/jemsi.v6i1.337.

\begin{abstract}
ABSTRAK:
Tujuan penelitian ini adalah untuk mengetahui faktor-faktor yang mempengaruhi kinerja pemasaran UMKM Aceh di masa Pandemi Covid 19. Lokasi penelitian ini dilakukan pada pelaku usaha kecil dan menengah di Aceh, metode penarikan sampel menggunakan metode non probability sampling dengan teknik penarikan sampel purposive sampling sehingga jumlah responden yang diperoleh sebanyak 93 orang pelaku usaha UMKM di Aceh. Peralatan analisis yang digunakan yaitu regresi linear berganda dalam model dan pengkajian hipotesis serta pengujian sebuah rangkaian hubungan relatif rumit secara simultan dan parsial. Hasil penelitian menunjukkan bahwa inovasi proses, dan inovasi pemasaran berpengaruh signifikan terhadap kinerja UMKM Aceh di masa pandemi Covid 19, dari hasil penelitian ini terlihat bahwa secara parsial dan simultan berpengaruh signifikan terhadap kinerja UMKM Aceh di masa pandemi Covid 19 dengan nilai signifikansi dibawah 0,05.
\end{abstract}

Kata Kunci: Inovasi Proses; Inovasi Pemasaran; Kinerja UMKM.

JEL Classification: A10; D04; 012.

\section{PENDAHULUAN}

Salah satu pelaku usaha yang paling terpukul akibat mewabahnya Covid-19 adalah Usaha Mikro Kecil dan Menengah (UMKM). Banyak dari mereka yang terpaksa harus gulung tikar lantaran tidak adanya pemasukan untuk memenuhi kebutuhannya alias pemasukannya yang merosot selama pandemi, ada beberapa faktor lain yang membuat para pelaku UMKM kesulitan mendapatkan pemasukan. Pertama disebabkan adanya beberapa kesulitan-kesulitan selama proses produksi. Seperti harga bahan baku yang meningkat, bahan baku yang tidak tersedia, pengiriman bahan baku yang lama, proses produksi yang menjadi lama dan banyaknya karyawan yang lebih memilih untuk pulang kampung. Sekitar 30 Juta UMKM Tutup karena Pandemi Covid-19 dan sebanyak 60 persen pelaku UMKM yang mengaku bahwa naiknya harga bahan baku menjadi faktor utamanya. Lalu ada 18 persen pelaku UMKM yang mengaku bahwa bahan baku tidak tersedia sama sekali. "Kalaupun bahan baku ada, proses untuk mendapatkannya yang lama, ada sebanyak 12 persen yang mengaku bahwa mereka lama mendapatkan bahan baku. Lalu ada 10 persen yang mengaku kalau proses produksi menjadi lama dan 10 persen lagi yang mengaku bahwa karyawannya lebih memilih untuk pulang kampung. Lalu faktor yang kedua, adalah banyaknya para pelaku UMKM yang mengalami kesulitan penjualan selama pandemi(https://money.kompas.com/read).

Faktor pendukung yang membuat para pelaku UMKM kesulitan menjual produknya adalah jumlah pelanggan yang berkurang, kesulitan dalam mendapatkan modal usaha, ketidakpastian PSBB berakhir, tidak bisa menerima pelanggan di tempat, pembatasan jam operasional dan masih banyak lainnya. Kalau dipersentasekan ada sebanyak 73 persen yang mengeluh karena pelanggan berkurang, dan sebanyak 46 persen yang mengeluh karena kesulitan dalam mendapatkan modal usaha. Kemudian ada sebanyak 40 persen yang mengeluh karena tidak bisa menerima pelanggan di tempat. PSBB membuat banyak outlet yang jam operasionalnya dikurangi, apalagi semenjak masyarakat disuruh di rumah aja mereka lebih banyak memilih untuk mengurangi aktivitas di 
luar sehingga para UMKM ini untuk terus bertahan harus bergantung pada penjualannya secara online (https://money.kompas.com).

Berdasarkan faktor-faktor diatas menunjukkan bahwa kinerja pemasaran pada produk UMKM dimasa pandemi covid 19 mengalami penurunan yang cukup signifikan, sehingga para pelaku UMKM dapat menggunakan langkah-langkah yang terukur dalam memaksimalkan pemasaran produk UMKM diantaranya inovasi proses, dan inovasi pemasaran, dimana inovasi proses sebagai teknik dan proses baru yang diperkenalkan ke dalam operasi usaha yang membantu meningkatkan efisiensi atau efektivitas, serta Inovasi proses, terkait dengan cara baru penyampaian produk ke konsumen sangat mungkin di lakukan. UMKM dapat menggunakan media online untuk menyampaikan produk mereka ke konsumen dan menurunkan biaya produksi demikian juga inovasi pemasaran produk UMKM selama ini lebih banyak mengandalkan penjualan langsung ke konsumennya dan dimasa pandemi akses konsumen ke pasar produk UMKM sangat terbatas sehingga berdampak pada penurunan penjualan produk UMKM.

Membangun pemasaran produk UMKM diperlukan adanya usaha-usaha dari pelaku usaha untuk tetap memberikan kualitas kinerja yang terbaik, sehingga membentuk persepsi kualitas yang kuat dibenak pelanggan, jika produk yang dipasarkan mempunyai kualitas yang baik, semakin banyak kesempatan pada pelaku usaha untuk mengibarkan brand produknya dan reputasi perusahaan selalu baik di mata masyarakat. Begitu juga sebaliknya jika pelaku usaha mempunyai kinerja yang buruk maka akan mengecewakan pelanggannya sehingga akan memperburuk eksistensi pelaku usaha yang akan berakibat menurunnya penjualan produk.

Situasi pandemi Covid-19 saat ini memberikan pukulan berat bagi para pelaku UMKM di antaranya kesulitan mendapatkan bahan baku, kesulitan permodalan, dan lainnya. Di sisi lain, kinerja UMKM yang kurang begitu baik di masa pandemi bisa mengurangi kepercayaan lembaga keuangan seperti perbankan dalam pengucuran kredit padahal masih banyak UMKM yang belum mendapatkan akses pembiayaan dari perbankan. Meski demikian, perbankan terus membuka peluang bagi UMKM melalui literasi dan inklusi keuangan. Pada Juli lalu, Kementerian Koperasi dan UKM melansir bahwa jumlah UMKM di Indonesia mencapai 64 juta unit usaha atau $99 \%$ dari total unit usaha di dalam negeri. Kontribusi UMKM terhadap PDB Nasional adalah sekitar 61\% (https://keuangan.kontan.co.id/news/).

\section{TINJAUAN KEPUSTAKAAN}

\section{Kinerja Pemasaran}

Kinerja pemasaran merupakan konstruk yang umum digunakan untuk mengukur dampak penerapan strategi perusahaan (Ferdinand, 2000:115). Dalam aplikasinya upaya tersebut menjadi satu kebutuhan untuk dilakukan dalam mengoptimalkan kinerja usaha. Market orientation memiliki peran yang sama penting dan dapat memberikan kontribusi terhadap peningkatan kinerja perusahaan (Hatani, 2000).

Menurut Perwiranegara, (2015) kinerja UKM merupakan hasil yang diinginkan organisasi dari perilaku orang-orang didalamnya. Kinerja organisasi merupakan tolak ukur tingkatkeberhasilan dan perkembangan organisasi. Morgan \& Berthon, (2008) juga menyatakan bahwa kinerja bisnis perusahaan secara signifikan tebentuk dari strategi inovasi eksploitatif. Dalam penelitian ini kinerja perusahaan diukur dari inovasi produk dan inovasi proses yang dapat meningkatkan kinerja dari perusahaan. Yang diperkuat dengan pendapat dari Morgan \& Berthon, (2008) yang menyatakan fitur baru, perbaikan, atau manfaat yang terkait dengan produk baru juga dapat meningkatkan kepuasan pelanggan, menarik pelanggan baru, dan mengembangkan segmen pasar baru, meningkatkan penjualan dan kinerja.

\section{Inovasi Proses}

Inovasi proses merupakan kegiatan inovasi proses yang menunjukkan apakah sebuah perusahaan memperkenalkan inovasi proses baru dalam proses produksinya atau tidak. Un \& Asakawa, (2015), Gunday et al.,(2011) mendefinifikan inovasi proses sebagai teknik dan proses baru yang diperkenalkan ke dalam operasi yang membantu meningkatkan efisiensi atau efektivitas, dan menurunkan biaya produksi. Menurut Martinez-ros \& Labeaga, (2009); Un \& Asakawa, (2015) inovasi proses adalah penerapan metode produksi atau pengiriman baru yang meningkat secara signifikan. Ini mencakup perubahan teknik, peralatan dan perangkat lunak yang signifikan. Berdasarka literatur diatas inovasi proses mengacu pada indikator (Zhang et al., 2017)

1. Perusahaan belajar lebih banyak tentang proses terbaru daripada pesaing.

2. Perusahaan merupakan yang pertama dalam industri untuk menerapkan proses baru.

3. Perusahaan mengikuti perkembangan proses terakhir.

4. Perusahaan sering memperkenalkan proses yang sangat berbeda dari proses yang ada di industri ini. 
Inovasi proses menggunakan penerapan metode produksi atau pengiriman yang benar-benar baru atau telah melalui peningkatan yang signifikan.

\section{Inovasi Pemasaran}

Inovasi pemasaran adalah penerapan metode pemasaran yang baru atau peningkatan signifikan pada pengemasan atau desain produk, penempatan produk, promosi produk, atau harga (Direktorat Inovasi dan Inkubator Bisnis UI). Inovasi pemasaran bertujuan untuk:

- Meningkatkan penjualan

- Memenuhi kebutuhan konsumen

- Membuka pasar baru

- Menempatkan produk perusahaan dalam pasar.

Perubahan pada metode memindahkan informasi atau barang dengan tujuan meningkatkan penjualan atau pangsa pasar. Persatuan Perusahaan Periklanan Indonesia (PPPI), telah merilis bahwa televisi dan digital masing-masing bakal menguasai 60 persen dan 25 persen pangsa iklan pada 2021. Sisanya dibagi untuk media lain, seperti radio dan media luar ruang. Pada Tahun 2021, sebenarnya memang agak sulit untuk diramalkan. Namun, tapi akan naik di kisaran 7,5 - 10 persen. Kenaikan bakal didominasi oleh media digital. TV persentase tetap paling besar, tapi digital akan menikmati pertumbuhan paling signifikan (https://ekonomi.bisnis.com).

\section{Kerangka Penelitian}

Untuk memperjelas hubungan antara variabel-variabel tersebut, maka disajikan paradigma (model hubungan) yang disesuaikan dengan situasi kinerja pemasaran UMKM di Aceh, dan selanjutnya menjadi kerangka pemikiran dalam penelitian ini, berikut ini:

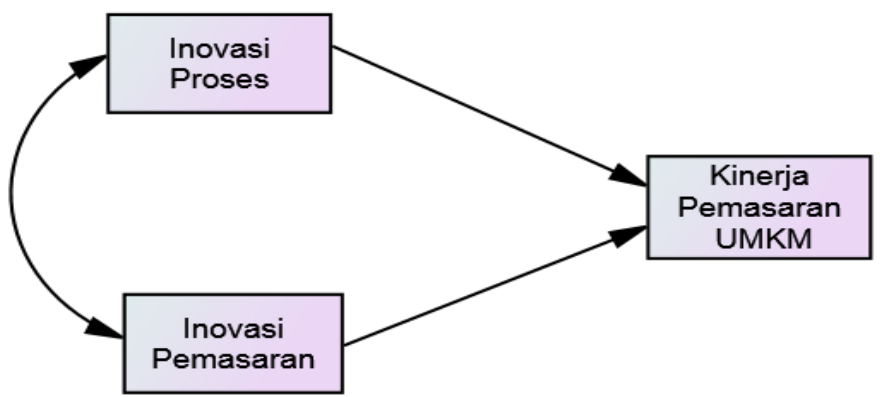

\section{Hipotesis Penelitian}

Gambar 1. Kerangka Pemikiran

Hipotesis dalam penelitian dibagi dibagi dua, seperti berikut ini:

$\mathrm{H}_{\mathrm{a} 1}$ : $\quad$ Terdapat pengaruh inovasi proses dan inovasi pemasaran berpengaruh terhadap kinerja pemasaran UMKM.

$\mathrm{H}_{\mathrm{a} 2}$ : $\quad$ Terdapat pengaruh inovasi proses berpengaruh terhadap kinerja pemasaran UMKM.

$\mathrm{H}_{\mathrm{a} 3}$ : $\quad$ Terdapat pengaruh inovasi pemasaran berpengaruh terhadap kinerja pemasaran UMKM

\section{METODE PENELITIAN}

\section{Populasi dan Sampel}

Adapun populasi yang ditetapkan dalam penelitian ini adalah seluruh pelaku usaha UMKM baik dalam skala kecil dan menengah di Aceh. Dalam penelitian ini metode penarikan sampel menggunakan metode non probability sampling serta teknik penarikan sampel yang digunakan menggunakan teknik purposive sampling, dimana yang dijadikan sampel adalah pemuda Aceh yang tetap melakukan kegiatan usaha dimasa pandemi covid 19 dan bersedia memberikan informasi, maka besarnya penarikan jumlah sampel penelitian adalah 93 orang.

\section{Metode Pengumpulan Data}

Dalam pengumpulan data, penelitian ini menggunakan kuisioner yang terdiri dari item-item pertanyaan yang dibagikan kepada pelaku usaha UMKM di Aceh yang memiliki usaha, sesuai dengan variabel yang diteliti. 


\section{Skala Pengukuran}

Untuk mengukur variabel, penelitian ini menggunakan skala interval dengan skala Likert berdasarkan lima rentangan. Skala Likert dapat digunakan untuk mengukur item-item pernyataan yang bersifat positif maupun negatif terhadap masalah yang diteliti. Pertanyaan dalam kuesioner diuji dengan menggunakan skala Likert 1-5.

\section{Teknik Analisis Data}

Teknik analisis data yang digunakan dalam penelitian ini adalah analisis regresi linear berganda digunakan untuk menaksir bagaimana keadaan (naik turunnya) variabel dependen, bila dua atau lebih variabel dependen sebagai faktor prediktor dimanipulasi (dinaik turunkan nilainya). Menurut Sugiyono (2012:277) bila dijabarkan secara matematis bentuk persamaan dari regresi linier berganda adalah sebagai berikut:

\section{Dimana:}

$$
Y=a+b_{1} X_{1}+b_{2} X_{2}+\varepsilon
$$

\begin{tabular}{|c|c|}
\hline Y & = Kinerja Pemasaran UMKM \\
\hline a & $=$ Konstanta \\
\hline$X_{1}$ & $=$ Inovasi Proses \\
\hline & = Inovasi Pemasaran \\
\hline$b_{1}$ dan $b_{2}$ & $\begin{array}{l}=\text { Koefisien Regresi } \mathrm{X}_{1} \text { dan } \mathrm{X}_{2} \\
=\text { Error term }\end{array}$ \\
\hline
\end{tabular}

\section{Uji Hipotesis}

Hipotesis penelitian ini akan di uji dengan pengujian statistik uji t dan statistik uji $F$.

1. Uji Statistik F

Menurut Sugiyono (2012:264) uji F digunakan untuk menguji variabel-variabel bebas secara bersama-sama terhadap variabel terikat. Pengujian dilakukan dengan membandingkan nilai $F_{\text {hitung }}$ dengan $F_{\text {tabel }}$ pada derajat kesalahan $5 \%(0,05)$. Apabila nilai $F_{\text {hitung }}>F_{\text {tabel }}$ maka berarti variabel bebasnya secara serempak memberikan pengaruh yang bermakna terhadap variabel terikat. Selain itu dengan uji $F$ ini dapat diketahui pula apakah model regresi linier yang digunakan sudah tepat atau belum. Dasar pengambilan keputusan pengujian:

- Jika $F_{\text {hitung }}<F_{\text {tabel }}$ maka Ho ditolak

- Jika $F_{\text {hitung }}>F_{\text {tabel }}$ maka Ha diterima

Untuk pengujian digunakan hipotesa sebagai berikut:

- Ho : b1 = b2 =0, artinya secara bersama-sama tidak ada pengaruh variabel independen terhadap variabel dependen.

- $\mathrm{Ha}: \mathrm{b} 1 \neq \mathrm{b} 2=0$, artinya secara bersama-sama ada pengaruh variabel independen terhadap variabel dependen.

Pengujian ini dilakukan untuk membandingkan nilai $F_{\text {hitung }}$ dengan $F_{\text {tabelj }}$ ika $F_{\text {hitung }}>F_{\text {tabel, }}$ maka Ha diterima artinya variabel independen secara bersama-sama mempengaruhi variabel independen dan jika $F_{\text {hitung }}<F_{\text {tabel, }}$, maka Ho ditolak artinya variabel independen secara bersama-sama tidak mempengaruhi variabel dependen.

\section{Uji Statistik t}

Menurut Sugiyono (2012:244) uji t pada dasarnya menunjukkan seberapa jauh pengaruh suatu variabel penjelas secara individual dalam menerangkan variasi variabel terikat. Pengujian dilakukan dengan membandingkan antara nilai thitung masing-masing variabel bebas dengan nilai tabel dengan derajat kesalahan $5 \%$ $(0,05)$, apabila nilai $t_{\text {hitung }}>t_{\text {tabel }}$, maka variabel bebasnya memberikan pengaruh bermakna terhadap variabel terikat. Dasar pengambilan keputusan pengujian:

- Jika $t_{\text {hitung }}<t_{\text {tabel }}$ maka Ho ditolak

- Jika thitung $>t_{\text {tabel }}$ maka Ha diterima

Dalam uji t ini digunakan perumusan bentuk hipotesis sebagai berikut :

- $\mathrm{Ho}:$ bi $=0$, artinya variabel bebas secara parsial tidak berpengaruh terhadap variabel terikat.

- $\mathrm{Ha}: \mathrm{bi} \neq 0$, artinya variabel bebas secara parsial berpengaruh terhadap variabel terikat

Dimana bila bi adalah koefisien variabel ke I nilai parameter hipotesis dan biasanya dianggap $=0$ (nol). Artinya tidak ada pengaruh variabel $\mathrm{X}$ terhadap $\mathrm{Y}$. Pengujian ini dilakukan dengan menggunakan uji t dengan membandingkan thitung dengan $t_{\text {tabel. }}$. 


\section{HASIL PENELITIAN DAN PEMBAHASAN}

\section{Hasil Analisis Regresi}

Sesuai dengan peralatan analisis data yang digunakan untuk mengetahui hubungan fungsional antara variabel yang diteliti dalam penelitian ini dengan menggunakan analisis regresi linier berganda. Untuk melihat kinerja pemasaran pada UMKM Aceh di masa pandemi Covid 19 maka perlu mengetahui pengaruh inovasi proses dan inovasi pemasaran terhadap kinerja pemasaran pada UMKM Aceh di masa pandemi Covid 19. Hal ini ditunjukkan oleh nilai koefisien regresi masing-masing variabel seperti terlihat pada Tabel 2.

Tabel 1. Hasil Analisis Regresi

\begin{tabular}{|c|c|c|c|c|c|c|c|}
\hline \multicolumn{8}{|c|}{ Coefficients $^{\mathrm{a}}$} \\
\hline \multirow[t]{2}{*}{ Model } & \multicolumn{2}{|c|}{$\begin{array}{c}\text { Unstandardized } \\
\text { Coefficients } \\
\end{array}$} & \multirow{2}{*}{$\begin{array}{c}\begin{array}{c}\text { Standardized } \\
\text { Coefficients }\end{array} \\
\text { Beta }\end{array}$} & \multirow[t]{2}{*}{$t$} & \multirow[t]{2}{*}{ Sig. } & \multicolumn{2}{|c|}{$\begin{array}{c}\text { Collinearity } \\
\text { Statistics }\end{array}$} \\
\hline & $B$ & $\begin{array}{l}\text { Std. } \\
\text { Error }\end{array}$ & & & & $\begin{array}{c}\text { Tolera } \\
\text { nce }\end{array}$ & VIF \\
\hline (Constant) & .549 &, 418 & & 1,315 & ,192 & & \\
\hline Inovasi proses & .648 &, 091 & .575 & 7,118 &, 000 & 931 & 1,074 \\
\hline $\begin{array}{l}\text { Inovasi } \\
\text { pemasaran }\end{array}$ & 237 &, 083 &, 231 & 2,857 &, 005 &, 931 & 1,074 \\
\hline
\end{tabular}

a. DependentVariable:Kinerja Pemasaran UMKM

Sumber: Data Primer (Diolah), 2020.

Berdasarkan Tabel 1 maka persamaan regresi yang memperlihatkan kinerja pemasaran pada UMKM Aceh di masa pandemi Covid 19 sebagai fungsi dari inovasi proses dan inovasi pemasaran, dapat diformulasikan dalam persamaan berikut:

$$
Y=0,549+0,648 X_{1}+0,237 X_{2}+\varepsilon
$$

Dari persamaan regresi diatas dapat diketahui bahwa hasil penelitian sebagai berikut :

\section{Koefisien Regrisi $(\beta)$}

Adapun koefisien regrisi linier berganda dalam penelitian ini dapat dijelaskan sebagai berikut:

1. Konstanta sebesar 0,549 artinya jika inovasi proses $\left(X_{1}\right)$ dan inovasi pemasaran $\left(X_{2}\right)$ dianggap konstan, maka besarnya kinerja pemasaran pada UMKM Aceh di masa pandemi Covid 19 adalah sebesar 0,549 pada satuan skala likert.

2. Koefisien regresi inovasi proses $\left(X_{1}\right)$ sebesar 0,648 , artinya bahwa setiap $100 \%$ perubahan dalam variabel inovasi proses, maka secara relatif akan mempengaruhi kinerja pemasaran pada UMKM Aceh di masa pandemi Covid 19 sebesar 64,9\%, maka semakin tinggi inovasi proses maka akan mempengaruhi kinerja pemasaran pada UMKM Aceh di masa pandemi Covid 19.

3. Koefisien regresi inovasi pemasaran $\left(X_{2}\right)$ sebesar 0,237 , artinya bahwa setiap $100 \%$ perubahan dalam variabel inovasi pemasaran, maka secara relatif akan mempengaruhi kinerja pemasaran pada UMKM Aceh di masa pandemi Covid 19 sebesar 23,7\%, dengan demikian semakin tinggi inovasi pemasaran maka akan semakin mempengaruhi kinerja pemasaran pada UMKM Aceh di masa pandemi Covid 19 .

Berdasarkan hasil analisis regresi linier berganda, maka dapat diketahui bahwa dari kedua variabel yang diteliti, ternyata variabel inovasi proses $\left(X_{1}\right)$ yang mempunyai pengaruh paling dominan terhadap kinerja pemasaran pada UMKM Aceh di masa pandemi Covid 19 , dengan nilai koefesien sebesar 0,648 dan diikuti oleh variabel inovasi pemasaran $\left(\mathrm{X}_{2}\right)$ mempunyai nilai koefisien sebesar 0,237 .

\section{Koefisien Korelasi dan Determinasi}

Untuk melihat hubungan dan pengaruh dari variabel inovasi proses dan inovasi pemasaran terhadap kinerja pemasaran pada UMKM Aceh di masa pandemi Covid 19, berdasarkan korelasi dan determinasi dapat dilihat pada Tabel 3 . 
Tabel 2. Koefisien Korelasi dan Determinasi

Model Summary

\begin{tabular}{|l|r|r|r|r|}
\hline Model & $\mathrm{R}$ & R Square & \multicolumn{1}{c|}{$\begin{array}{c}\text { Adjusted } \mathrm{R} \\
\text { Square }\end{array}$} & $\begin{array}{l}\text { Std. Error of the } \\
\text { Estimate }\end{array}$ \\
\hline 1 &, $673^{\mathrm{a}}$ &, 453 &, 441 &, 343 \\
\hline
\end{tabular}

a. Predictors: (Constant), Inovasi pemasaran, Inovasi proses

b. DependentVariable: Kinerja Pemasaran UMKM Karyawan

Sumber: Data Primer (Diolah), 2020

Berdasarkan Tabel 2 diatas, maka koefisien korelasi dan determinasi yaitu:

1. Koefisien korelasi (R) sebesar 0,673 yang menunjukkan bahwa derajat hubungan (korelasi) antara variabel bebas dengan variabel terikat sebesar 67,3\%, artinya kinerja pemasaran pada UMKM Aceh di masa pandemi Covid 19 mempunyai hubungan yang erat dan positif dengan inovasi proses $\left(X_{1}\right)$ dan inovasi pemasaran $\left(\mathrm{X}_{2}\right)$.

2. Korelasi determinasi $\left(R^{2}\right)$ sebesar 0,453 , artinya sebesar $45,3 \%$ perubahan-perubahan dalam variabel terikat yaitu kinerja pemasaran dapat dijelaskan oleh perubahan-perubahan dalam inovasi proses $\left(X_{1}\right)$ dan inovasi pemasaran $\left(\mathrm{X}_{2}\right)$, dan sisanya yaitu sebesar $54,7 \%$ dijelaskan oleh variabel lain diluar dari pada penelitian ini misalnya inovasi produk, inovasi distribusi, akses modal, kualitas pelayanan dan lain-lain.

\section{Uji Hipotesis}

Uji F (Simultan)

Hasil pengujian statistik menunjukkan nilai $F_{\text {hitung }}$ sebesar 3,318 nilai $F_{\text {tabel }}$ pada tingkat keyakinan 95 persen menunjukkan angka sebesar 3,111, karena nilai $F_{\text {hitung }}>F_{\text {tabel }}(37,318>3,111)$. Artinya inovasi proses $\left(X_{1}\right)$ dan inovasi pemasaran $\left(X_{2}\right)$ secara simultan berpengaruh signifikan terhadap kinerja pemasaran pada UMKM Aceh di masa pandemi Covid 19 , sehingga hipotesis Ha diterima.

\section{Uji t (Parsial)}

Uji t (parsial) dilakukan untuk mencari pengaruh variabel bebas terhadap variabel terikat dalam persamaan regresi secara parsial dengan mengasumsikan variabel lain dianggap konstan. Uji t dilakukan dengan membandingkan antara nilai thitung dengan nilai trabel, yaitu:

1. Hipotesis pertama pada variabel inovasi proses $\left(X_{1}\right)$ menunjukkan bahwa nilai thitung sebesar 7,118 dan nilai $t_{\text {tabel }}$ pada tingkat keyakinan $95 \%$ sebesar 1,988 , karena nilai $t_{\text {nitung }}>t_{\text {tabel }}(7,118>1,988)$. Artinya inovasi proses secara parsial berpengaruh terhadap kinerja pemasaran pada UMKM Aceh di masa pandemi Covid 19 , sehingga hipotesis pertama Ha diterima.

Hipotesis kedua untuk variabel inovasi pemasaran $\left(\mathrm{X}_{2}\right)$ menunjukkan nilai thitung sebesar 2,867 dan nilai tabel pada tingkat keyakinan $95 \%$ sebesar 2,017 , karena nilai $t_{\text {nitung }}>t_{\text {tabel }}(2,867>1,988)$. Artinya inovasi pemasaran secara parsial berpengaruh terhadap kinerja pemasaran pada UMKM Aceh di masa pandemi Covid 19 , sehingga hipotesis kedua Ha diterima.

\section{KESIMPULAN DAN SARAN}

\section{Kesimpulan}

1. Hasil pengujian statistik uji $\mathrm{F}$ menunjukkan bahwa nilai Fhitung $>$ Ftabel $(37,318>3,111)$. Artinya inovasi proses (X1) dan inovasi pemasaran (X2) secara simultan berpengaruh signifikan terhadap kinerja pemasaran pada UMKM Aceh di masa pandemi Covid 19.

2. Hasil pengujian statistik uji t variabel inovasi proses menunjukkan nilai thitung $>$ ttabel $(7,188>1,988)$. Artinya inovasi proses secara parsial berpengaruh terhadap kinerja pemasaran pada UMKM Aceh di masa pandemi Covid 19.

3. Hasil pengujian statistik uji t variabel inovasi pemasaran menunjukkan nilai thitung>ttabel $(2,868>1,988)$. Artinya inovasi pemasaran secara parsial berpengaruh terhadap kinerja pemasaran pada UMKM Aceh di masa pandemi Covid 19.

4. Nilai koefisien korelasi $(R)$ sebesar 0,673 yang menunjukkan bahwa derajat hubungan (korelasi) antara variabel bebas dengan variabel terikat sebesar $67,3 \%$, artinya kinerja pemasaran pada UMKM Aceh di masa pandemi Covid 19 mempunyai hubungan yang erat dan positif dengan inovasi proses (X1) dan inovasi pemasaran (X2). 


\section{Saran}

Berdasarkan hasil penelitian maka peneliti ingin menyampaikan saran kepada kantor Dinas Perhubungan Provinsi Aceh sebagai berikut:

1. Pelaku UMKM Aceh di masa pandemi Covid 19 harus memaksimalkan kinerja pemasaran dengan memperhatikan inovasi proses dan inovasi pemasaran pada produk UMKM yang dipasarkan agar mudah diakses dan dipesan oleh pelanggan. Hal ini karena dalam penelitian ini ditemukan bahwa inovasi proses dan inovasi pemasaran berpengaruh signifikan terhadap kinerja pemasaran.

2. Pelaku UMKM Aceh di masa pandemi Covid 19 hendaknya lebih kreatif dalam melakukan terobosan inovasi pada produk UMKM yang dipasarkan secara cepat dan tanggap serta melakukan inovasi sesuai kebutuhan usaha. Inovasi dapat dilakukan dengan berbagai cara, seperti, meningkatkan layanan produk dengan fitur yang lebih canggih, dan go digital.

3. Pelaku UMKM Aceh di masa pandemi Covid 19 juga harus memperhatikan beberapa hal yang berkaitan dengan inovasi proses, dimana Inovasi proses, terkait dengan cara baru penyampaian produk ke konsumen sangat mungkin di lakukan. UMKM dapat menggunakan media online untuk menyampaikan produk mereka ke konsumen.

\section{REFERENSI}

[1] Direktorat Inovasi dan Inkubator Bisnis UI (2016).

[2] Ferdinand, Augusty.(2000). Manajemen Pemasaran : Sebuah Pendekatan Stratejik, Research Paper Series. Seri Penelitian Manajemen, No. 01/Mark/01/2000.

[3] Gunday, Gurhan, Gunduz Ulusoy, Kemal Kilic, and Lutfihak Alpkan. 2011. Effects of Innovation Types on Firm Performance. International Journal of Production Economics. 133(2): 662-76.

[4] Hatani, La. (2000). Pengaruh Orientasi Pasar Terhadap Kinerja Pemasaran di Kabupaten Muna. Jurnal Manajemen Unhalu. Hal: 1-9.

[5] Martínez-Ros, E., \& Labeaga, J. (2009). Product and process innovation: Persistence and complementarities. European Management. Review, 6(1), 64-75.

[6] Mukhdasir dan Almhafud Sahputra. (2019) Dukungan Keberanian Kewirausahaan Pemuda Aceh. Jurnal Ekonomi dan Akuntansi, Vol 5 , No.2

[7] Perwiranegara, Abdul Haris. 2015. Pengaruh Orientasi Kepemimpinan Pasar dan Strategi Inovasi Terhadap Kinerja UKM (Studi pada UKM Kerajinan Bubut Kayu Kota Blitar). Jurnal Aplikasi Manajemen (JAM), Vol 13, No $1 ; 77-89$

[8] Sugiyono. (2012). Memahami Penelitian Kualitatif. Bandung : ALFABETA.

[9] Un, C Annique, and Kazuhiro Asakawa. 2015. Types of R \& D Collaborations and Process Innovation : The Benefit of Collaborating Upstream in the Knowledge Chain ." 32(1): 138-53.

[10] Zhang, Shanshan, Zhiqiang Wang, Xiande Zhao, and Min Zhang. 2017. Effects of Institutional Support on Innovation and Performance: Roles of Dysfunctional Competition." Industrial Management \& Data Systems 117(1): 50-67

[11] https://money.kompas.com/read

[12] https://ekonomi.bisnis.com. 